\title{
Amoxicillin-associated rash in glandular fever
}

\author{
Richard Fox, ${ }^{1}$ Reshma Ghedia, ${ }^{2}$ Robert Nash ${ }^{2}$
}

'Department of ENT, Northwick Park Hospital, London, UK

${ }^{2}$ Department of ENT, Charing Cross Hospital, London, UK

\section{Correspondence to} Dr Richard Fox, richardfox@doctors.org.uk

Accepted 31 August 2015
CrossMark

To cite: Fox R, Ghedia $R$, Nash R. BMJ Case Rep Published online: [please include Day Month Year] doi:10.1136/bcr-2015211622

\section{DESCRIPTION}

Glandular fever, otherwise termed infectious mononucleosis, is a common cause of severe pharyngitis in adolescents and young adults. It is associated with acute Epstein-Barr virus infection. It is recognised that in the context of acute glandular fever, some antibiotics, notably ampicillin and amoxicillin, may lead to severe, generalised rashes that involve the extremities. ${ }^{1}$ The pathophysiology of the rash is unknown. ${ }^{2}$

We present a case of an 18-year-old patient who presented to their general practitioner with an acute history of sore throat and fever. Amoxicillin was prescribed, and the patient developed a widespread, non-blanching, maculopapular rash $48 \mathrm{~h}$ after starting treatment (figures 1 and 2). The patient had no known allergies and no prior allergy testing. A Monospot test was positive for glandular fever. Amoxicillin was discontinued, and the rash subsequently improved gradually over the following 3 weeks.

Antibiotic treatment is not routinely indicated for the treatment of either pharyngitis or glandular fever. ${ }^{3}$ When indicated, phenoxymethylpenicillin is preferred to amoxicillin due to the lower incidence of antibiotic-associated rashes.

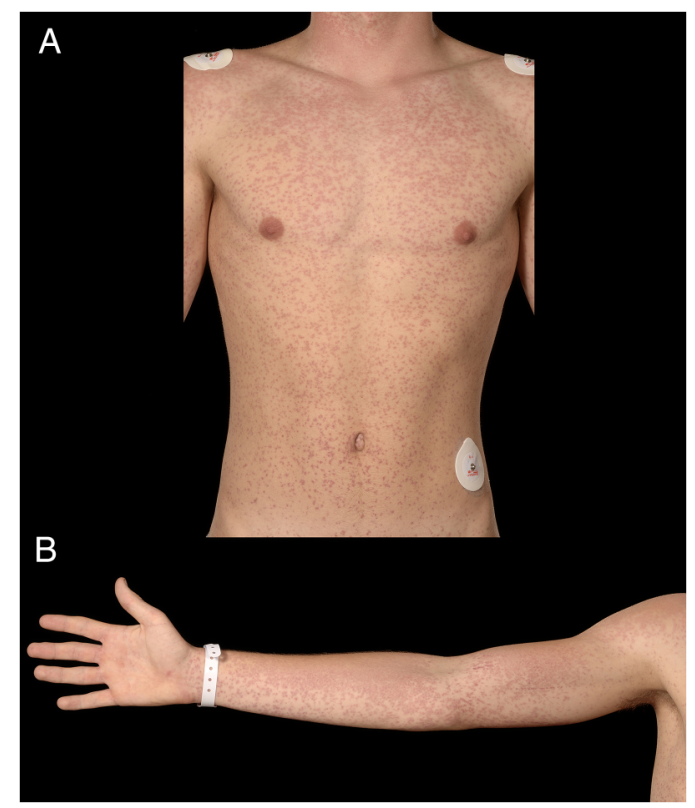

Figure 1 Clinical photograph of the torso $(A)$ and right arm (B) demonstrating a maculopapular rash.

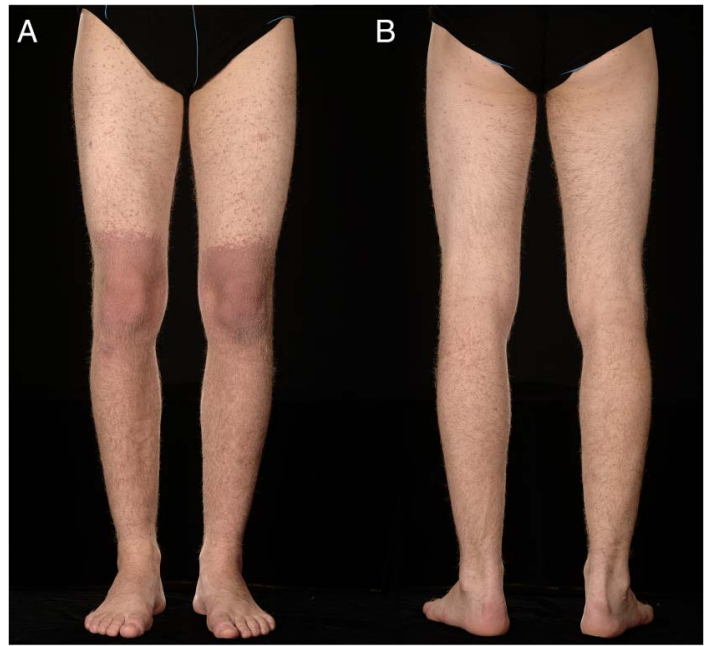

Figure 2 Clinical photograph of the lower limbs ((A) Anterior and (B) Posterior) demonstrating a maculopapular rash.

\section{Learning points}

- Ampicillin and amoxicillin should be avoided in patients with pharyngitis when glandular fever is considered a possibility.

- Antibiotic treatment is not routinely indicated for pharyngitis and glandular fever.

- Phenoxymethylpenicillin (penicillin V) may substitute amoxicillin/ampicillin in cases when antibiotic therapy is desired.

Competing interests None declared.

Patient consent Obtained.

Provenance and peer review Not commissioned; externally peer reviewed.

\section{REFERENCES}

1 Chovel-Sella A, Ben Tov A, Lahav E, et al. Incidence of rash after amoxicillin treatment in children with infectious mononucleosis. Pediatrics 2013;131:e1424-7.

2 Ónodi-Nagy K, Kinyó Á, Meszes A, et al. Amoxicillin rash in patients with infectious mononucleosis: evidence of true drug sensitization. Allergy Asthma Clin Immunol 2015;11:1.

3 Cooper RJ, Hoffman JR, Bartlett JG, et al. Principles of appropriate antibiotic use for acute pharyngitis in adults: background. Ann Emerg Med 2001:37:711-19. 
Copyright 2015 BMJ Publishing Group. All rights reserved. For permission to reuse any of this content visit http://group.bmj.com/group/rights-licensing/permissions.

BMJ Case Report Fellows may re-use this article for personal use and teaching without any further permission.

Become a Fellow of BMJ Case Reports today and you can:

- Submit as many cases as you like

- Enjoy fast sympathetic peer review and rapid publication of accepted articles

- Access all the published articles

- Re-use any of the published material for personal use and teaching without further permission

For information on Institutional Fellowships contact consortiasales@bmjgroup.com

Visit casereports.bmj.com for more articles like this and to become a Fellow 